\title{
Combining Remote Sensing and Field Mapping Methods to Study the Vegetation Dynamics within a Coastal Wetland and Determine the Habitat Effects of a Threatened Bird Species (Emberiza schoeniclus witherbyi)
}

\author{
Luis Carrasco $^{\dagger *}$, Pablo Vera ${ }^{\ddagger}$, Eduardo J. Belda ${ }^{\S}$, and Juan S. Monrós ${ }^{\ddagger}$ \\ ${ }^{\dagger}$ Centre for Ecology and Hydrology \\ Lancaster Environmental Centre \\ Bailrigg LA1 4AP, England, U.K. \\ ${ }^{*}$ Institute Cavanilles of Biodiversity \\ and Evolutionary Biology \\ University of Valencia \\ Paterna ES-46980, Spain
}

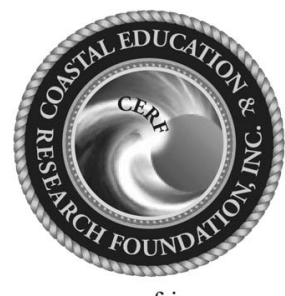

www.cerf-jcr.org

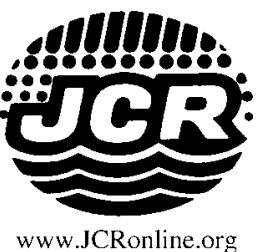

www.JCRonline.org

\begin{abstract}
Carrasco, L.; Vera, P.; Belda, E.J., and Monrós, J.S., 0000. Combining remote sensing and field mapping methods to study the vegetation dynamics within a coastal wetland and determine the habitat effects of a threatened bird species (Emberiza schoeniclus witherbyi). Journal of Coastal Research, 00(0), 000-000. Coconut Creek (Florida), ISSN 07490208 .

Coastal wetlands are highly dynamic changing ecosystems because of the effects of meteorology, wildlife interactions and human activities. They are one of the world's most threatened ecosystems, and threats to them drive the most specialist species to unfavorable conservation status and population trends. Therefore, it is important to frequently monitor the coverage changes of the different vegetation types to understand these species' population dynamics. However, frequent and detailed cartography entails costly efforts. Here, satellite images with field mapping were combined to create vegetation classification maps for past years from SPOT-5 images in the Pego-Oliva coastal wetland (Spain) and obtained classification accuracies above $85 \%$. Together with habitat selection models, this information was used to understand the changes in the habitat of a threatened bird species, the Eastern Iberian reed bunting (Emberiza schoeniclus witherbyi), whose population has sharply declined in recent decades in Spain. A statistically significant reduction in reed-rush patches (positively selected habitat) and an increase in homogeneous reed patches (negatively selected habitat) were observed in those areas where the species disappeared as breeders. This study shows the potential of remote sensing and GIS techniques for the a posteriori monitoring of variation in the habitats available for threatened species to set up management and conservation measures.
\end{abstract}

ADDITIONAL INDEX WORDS: Habitat selection, Mediterranean wetland, reed bunting, SPOT-5, vegetation classification map.

\section{INTRODUCTION}

Wetlands are among the world's most threatened ecosystems (Dudgeon et al., 2006; Strayer and Dudgeon, 2010). Loss or degradation of habitat, overexploitation, water pollution, modification of hydrological cycles, and invasive species all threaten the biological communities of wetlands (Allan and Flecker, 1993; Darwall et al., 2009; Revenga et al., 2005). High productivity levels and strong selection pressure make these ecosystems excellent sites for biodiversity, which include species of notable conservation interest, e.g., marshland birds (Dudgeon et al., 2006; Haig and Mehlman, 1998), some of which are sensitive to habitat changes (Martínez-Vilalta et al., 2002; Poulin and Lefebvre, 2002; Poulin, Lefebvre, and Mauchamp, 2002; Tanneberger et al., 2009). Because coastal wetlands are highly dynamic ecosystems, studying the habitats of the species that live there is difficult (Mialon, Roger, and Fily, 2005). This is why new methodologies based on mapping techniques are being rapidly developed to monitor and plan conservation strategies for these ecosystems (Davranche,

DOI: $10.2112 /$ JCOASTRES-D-16-00194.1 received 20 October 2016; accepted in revision 7 March 2017; corrected proofs received 7 May 2017; published pre-print online 14 July 2017.

*Corresponding author: luirra@ceh.ac.uk

${ }^{\circ}$ Coastal Education and Research Foundation, Inc. 2017
Lefebvre, and Poulin, 2009; Klemas, 2011; Poulin, Davranche, and Lefebvre, 2010).

In these dynamics systems, given the need to create cartographies in short time intervals, satellite images greatly reduce the effort required and economic costs of systematically mapping vegetation in situ. Nevertheless, the selection of appropriate satellite images and vegetation classification methodologies is not a trivial issue (Klemas, 2013). Suitable spectral and spatial resolutions, together with sufficient satellite revisiting frequency, are crucial to identify the complex wetland vegetation types correctly (De Roeck et al., 2008; Melack and Hess, 2004). Accurate vegetation mapping is especially important for those ecologists studying how habitat changes are affecting animal populations (Rocchini et al., 2011).

Combining maps of habitat changes with predictive habitat models using GIS methodologies provides an excellent tool for analyzing the dynamics of bird populations when population data are scarce or nonexistent. Until quite recently, most analyses of bird habitats have used low-spatial-resolution images, such as Landsat images (Gottschalk, Huettmann, and Ehlers, 2005; Shirley et al., 2013). However, higherspatial-resolution maps allow researchers to deal with new studies of the combined dynamics of habitats and species' 
populations based on predictive habitat models created on a small spatial scale (Keith et al., 2009; Leyequien et al., 2007; Turner et al., 2003).

The species selected for this study was the Eastern Iberian reed bunting (Emberiza schoeniclus witherbyi, hereafter called the reed bunting), an endemic subspecies of the Western Mediterranean Basin (Byers, Olson, and Curson, 1995). The population of this subspecies has sharply declined in the last decades, and its Spanish population includes only 250 to 350 breeding pairs, according to a census in 2005, which were found mainly in wetlands in the Castilla-La Mancha region (Atienza, 2006). Therefore, this subspecies is listed as endangered in the Red Book of Spanish Birds (Madroño, González, and Atienza, 2004) following International Union for Conservation of Nature criteria, and is on the Spanish List of Threatened Species (Catálogo Nacional de Especies Amenazadas, Real Decreto 139/2011). In the Marjal de Pego-Oliva Natural Park, a small coastal wetland of Eastern Spain, this subspecies was recorded as a breeder between the 1990s and 2007 (Atienza, 2006; Vera et al., 2009).

The present study had two objectives: (1) to obtain a classification of the vegetation in Marjal de Pego-Oliva, a highly dynamic coastal wetland, for previous years by combining fieldwork and SPOT-5 images and (2) to analyze vegetation changes in association with the local-scale decline of the reed bunting, a species with strong habitat selection.

\section{METHODS}

The methodology is based on two main phases: the creation of vegetation maps and the analysis of the changes in the key habitats for the study species. A field-based map of the study area was combined with satellite images of previous years to obtain vegetation classification maps. These maps were then used to analyze temporal changes, at different scales, in the positively and negatively selected habitats of the study species.

\section{Study Area}

This study was carried out in the Marjal de Pego-Oliva Natural Park, a 1290-hectare wetland located in the east of the Iberian Peninsula ( $38^{\circ} 52^{\prime} \mathrm{N}, 0^{\circ} 3^{\prime} \mathrm{W}$; Figure 1), which is included in the Natura 2000 Network. Vegetation is dominated mainly by common reed (Phragmites australis), cattails (Typha angustifolia), rushes (Juncus acutus and J. maritimus), and bulrushes (Scirpus maritimus, S. lacustris, and S. holoschoenus) and presents interannual variations that correspond to the superficial or phreatic water levels and to the management of the habitat for hunting purposes. The surroundings of the wetland habitats are characterized by the presence of a mosaic of crops, rice fields, dispersed reed patches, humid grasslands, and temporary ponds.

\section{Field Map}

To perform a multiseason analysis of vegetation, a vegetation map of Marjal de Pego-Oliva charted in situ between May and June 2008 was used as a reference. The following vegetation types were charted: common reed, cattails, and rushes (J. acutus, S. holoschoenus, and other rushes with similar ecological roles). Water channels, farmland tracks, paddy fields, and buildings were also charted, with each variable mutually exclusive from the other variables. Given the need for

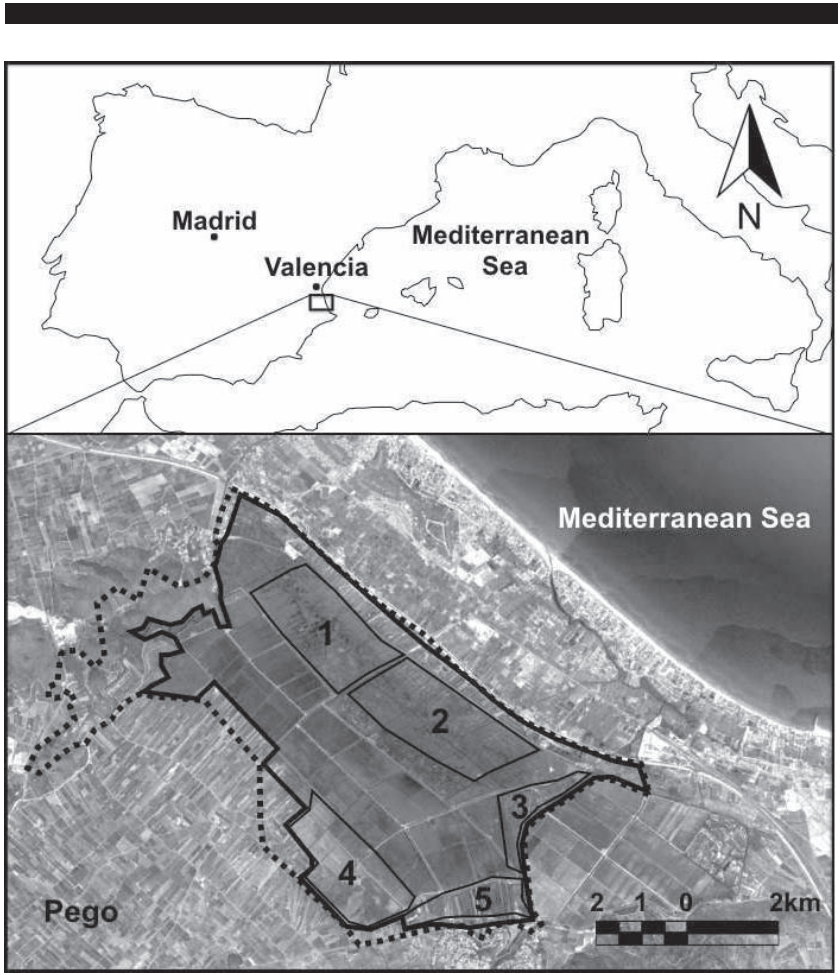

Figure 1. Location map of the study area. The dotted line represents the Marjal de Pego-Oliva Natural Park limits and the thick solid line comprises the palustrian vegetation and rice fields. Thin solid lines represent the highinterest regions. These regions were by delimited by considering the areas with a high probability of occurrence of a territorial male $(>80 \%)$ based on the habitat selection models in Vera et al. (2014).

high-spatial-resolution vegetation mapping, aerial photographs close in time to 2008 were used to help to georeference the vegetation unity limits with GPS. Subsequently, field data were transformed into digital polygons using the ArcMap software (Environmental Systems Research Institute, 2009).

\section{Processing and Classifying SPOT-5 Images}

SPOT-5 images were obtained through the Programa Nacional de Teledetección (PNT; Spanish National Geographical Institute). Images taken between June and August in 2005, 2006,2008 , and 2009 were used. No images of sufficient quality taken in 2007 were available because of high cloud coverage on the satellite overpass dates required for this study. SPOT-5 multispectral images have four bands (b1: 0.50-0.59 $\mu \mathrm{m}$; b2: 0.61-0.68 $\mu \mathrm{m}$; b3: 0.79-0.89 $\mu \mathrm{m}$; b4: 1.58-1.75 $\mu \mathrm{m})$, presenting a spatial resolution of $10 \mathrm{~m}$ for bands b1, b2, and b3 and $20 \mathrm{~m}$ for $\mathrm{b} 4$. This spatial resolution is adequate for performing vegetation classification studies in wetlands (Poulin, Davranche, and Lefebvre, 2010). Satellite images were preprocessed at level 1A (http://www.intelligence-airbusds.com) and geometric correction with the nearest-neighbor interpolation algorithm was applied (Davranche, Lefebvre, and Poulin, 2009).

Following this, a relative atmospheric correction, using the dark subtract algorithm (Chuvieco, 2002), was performed. The dark subtract correction allows a multitemporal analysis to be 
Table 1. Description of landcover classes used for the supervised classification. Four dominance categories were established for vegetation formations: (1) pure, when one species represented $95 \%$ to $100 \%$ of the cover of the vegetation patch mapped; (2) dominance, when a species represented $75 \%$ to $95 \%$; (3) codominance, when two species covered similar areas of $40 \%$ to $60 \%$ (i.e. reed-rush); (4) semidominance, when one species represented $60 \%$ to $75 \%$ and a second species represented $25 \%$ to $40 \%$ of the patch (i.e. reed with rushes).

\begin{tabular}{|c|c|c|}
\hline Landcover Class & Description & Correspondence to Field Map Formations \\
\hline Reed & Common reed (Phragmites australis) & Pure reedbed \\
\hline Reed-rushes & $\begin{array}{l}\text { Common reed with Juncus and other } \\
\text { structurally similar species }\end{array}$ & $\begin{array}{l}\text { Codominance and semidominance of reedbeds } \\
\text { with rushes }\end{array}$ \\
\hline Reed-cattail & Common reed with cattails (Typha angustifolia) & $\begin{array}{l}\text { Codominance and semidominance of reedbeds } \\
\text { with cattails }\end{array}$ \\
\hline Grassland & Herbaceous species and/or grasses & Pure grassland \\
\hline Rushes & Juncus and other structurally similar species & Pure or semidominance of rushes \\
\hline Reed-bulrushes & $\begin{array}{l}\text { Common reed with bulrushes (Scirpus } \\
\text { maritimus, S. lacustris, S. holoschoenus) }\end{array}$ & $\begin{array}{l}\text { Codominance or semidominance of reedbeds } \\
\text { and bulrushes }\end{array}$ \\
\hline Water & Ponds and channels & Open water \\
\hline Paddy field & Rice cultivations & Paddy field \\
\hline Flooded paddy & $\begin{array}{l}\text { Rice cultivations with the presence of a thin } \\
\text { water layer }\end{array}$ & Paddy field \\
\hline Crops & Vegetable cultivations & Crops \\
\hline Citrus & Citrus fruits cultivations & Citrus \\
\hline Building & Buildings, roads, and other constructions & Building \\
\hline
\end{tabular}

performed without obtaining the absolute reflectance values of the vegetation for each image, which thus provides a simpler and more reliable workflow (Keith et al., 2009; Martin, Howarth, and Holder, 1998). Masks were applied to the clouds and the clouds' shadows, and these areas were left out of the classification process.

The vegetation classification process was carried out by applying a supervised classification (Richards, 2006). Regions of interest (ROIs) were created for each image by identifying 12 landcover types that form the wetland and those detectable by satellite images (Table 1). Field map vegetation types were used to identify these landcover classes and to create the ROIs for 2008. For all other years, the visual interpretation was combined with the comparison of the spectral signatures to create ROIs (Martin, Howarth, and Holder, 1998). The vegetation patches for 2005,2006 , and 2009 were visually identified, with limits that coincided with the same patches in the 2008 image for all bands. This allowed the identification of temporary stable patches. To test the validity of this methodology, the spectral signatures of these patches were compared with those of the image taken from 2008 (Richards, 2006). If these geometrically constant patches had been replaced by another vegetation type, the spectral signature would have changed. After selecting some of these patches as ROIs, a spectral separability analysis (Richards, 2006) was performed to avoid identifying land regions that were too complex, which could affect the quality of the vegetation classification. With the selected ROIs, a supervised classification was made using a maximum likelihood algorithm. ENVI 4.3 (ITT Visual Information Solutions, Boulder, Colorado, U.S.A.) was used to perform the spectral separability analysis and the supervised classification.

To measure the validity of the classification for the 2008 map, 100 random points were created and the classified land use was compared with that of the vegetation field map. ArcMap and Hawth's Tools for ArcMap (Beyer, 2002) were employed to create random points and to compare land uses between the two maps. Some land-use classes on the field map were joined to meet the supervised classification classes. To test the accuracy of the classification for the other years, a confusion matrix (Richards, 2006) was created by comparing the results with the ROI data and then calculating the overall accuracy index and the kappa coefficient (Congalton, 1991).

\section{Reed Bunting Population}

Each survey consisted of three linear transects. These covered all habitats within the study area and gave a total length of $15.02 \mathrm{~km}$ (Tr.1: $5.47 \mathrm{~km}$; Tr.2: $5.08 \mathrm{~km}$; Tr.3: $4.49 \mathrm{~km}$ ) and a lateral coverage of $100 \mathrm{~m}$. Surveys were conducted weekly from May to July between 2005 and 2009 to avoid coming into contact with late-migrating individuals belonging to the schoeniclus subspecies, which are located in the area until mid-April. Surveys lasted 4 hours and started at dawn or before sunset. Adverse weather conditions were always avoided. After visual or audio contact, the location of a territorial individual (singing, adding nest material, etc.) of feeding nestlings was georeferenced using a GPS, laser telemeter, and compass.

\section{Temporal Analysis of Reed Buntings' Preferred Habitats}

To study reed buntings' habitat preferences on both wetland and territory scales, the same methodology as used in previous studies with this species was followed (Vera et al., 2011, 2014). At both scales, the reed bunting selects heterogeneous habitats such as reed-rush and reed-cattail, habitats that are associated with provision of nesting and feeding resources and reduced predation risk. With the habitat variables measured on the wetland scale, the classified vegetation maps were used and the proportion of pixels of each vegetation type was calculated in relation to the number of the wetland's total pixels. The biggest patch for each class was also identified to detect changes on key pieces of habitat. Five high-interest regions within the wetland were defined (Figure 1). For these five regions, changes in the preferred vegetation types of reed buntings were analyzed to study their territories based on the previous habitat preferences studies of this species (Vera et al., 2014).

To study the habitat variables measured on the territory scale, 50 random points were plotted in the study area. Random points were different for each study year. Then, 100-m radius 


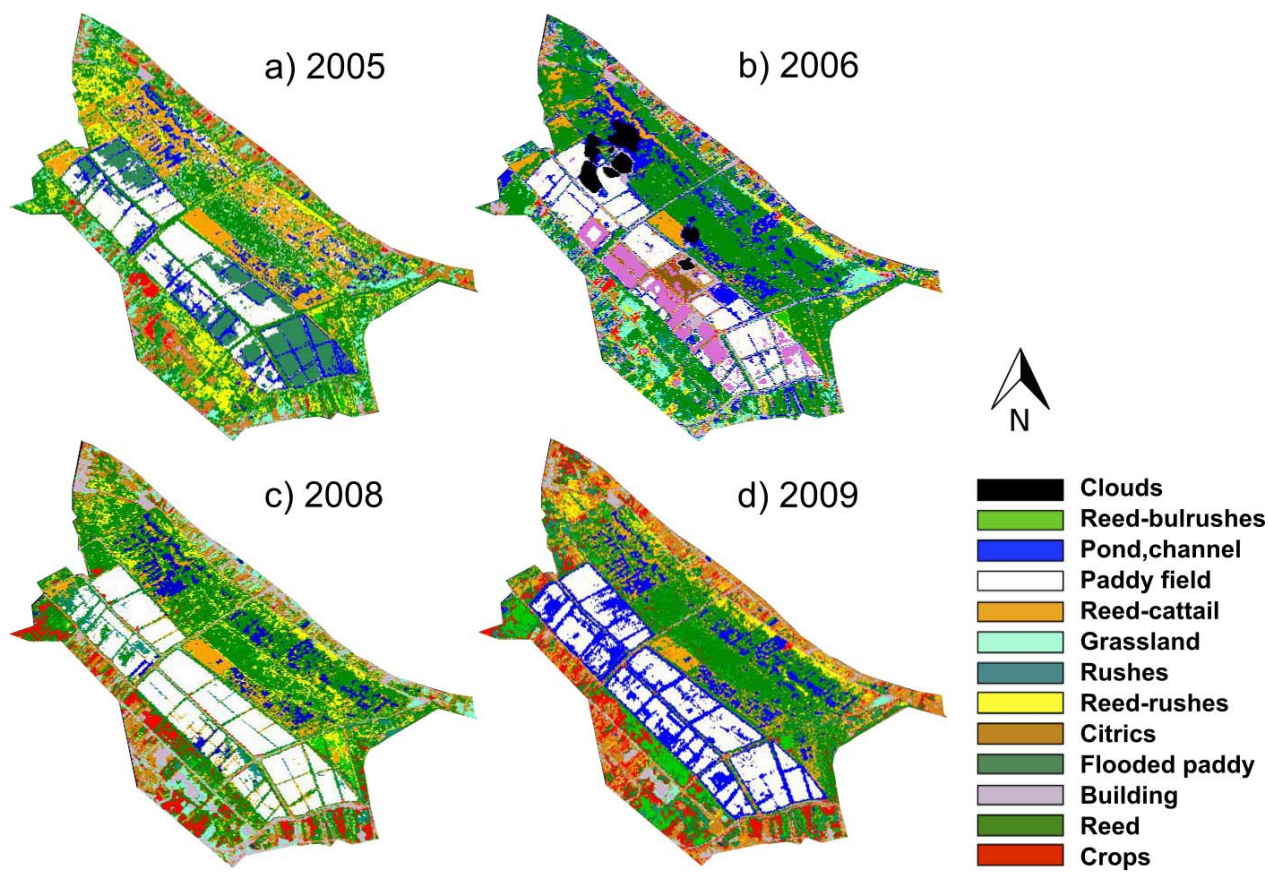

Figure 2. Vegetation classification maps for the four study years. The general darkening of the classifications from 2006 (excluding the central stripe, formed by paddy fields at different flooding stages) corresponds to an overall substitution of mixed vegetation formations to pure reed.

circular areas were created around those points (following the methodology implemented in Vera et al., 2014), which represented 50 possible breeding territories for reed buntings. Finally, the percentages of each vegetation type for each circular area were calculated using ENVI 4.3. ArcMap and Hawth's Analysis Tools (Beyer, 2002) were used to create the random points and circular areas.

\section{RESULTS}

A vegetation classification was obtained for 2005, 2006, 2008, and 2009 (Figure 2). When comparing the classification of 2008 with the field-based map, an accuracy of $74 \%$ was obtained. Some misclassified points were found in small crops or on bordering paths between different land types. The classification algorithm obtained values above $85 \%$ accuracy compared with the ROIs for all study years, with the most accurate at 96\%. The kappa coefficient values were always above 0.8 (Table 2). The classification accuracy for each class also varied from year to year, with reed and reed-bulrushes generally being the most accurate of the main wetland classes, while grassland and reedrushes presented lower accuracies (see confusion matrices and user-producer accuracies in Supplementary Appendix A).

Monitoring reed bunting data revealed the existence of five territorial males when the study began. In 2006, five territorial males were also detected, but only three males were found in 2007. No territorial males were detected in 2008 and 2009. All breeding territories were located in Region 1 (2005: one male; 2006: one male; 2007: zero males) and Region 2 (2005: four males; 2006: four males; 2007: three males).

Using the whole wetland as a reference, the areas and proportions of the main wetland vegetation classes, as well as the total pure reed surface and the biggest pure reed patch size, were estimated (Table 3 and Figures 3 and 4). The proportions of reed-cattail and reed-rush, habitats positively selected by reed buntings on the wetland scale (Vera et al., 2014), had reduced by more than $50 \%$ between 2005 and 2006 (Figure 3), while the pure reed surface had increased over the same period by more than $20 \%$ (Figure 4 ). This tendency was reversed in the following years as the reed surface had reduced (Figure 4) and the proportion of mixed formations, preferred by reed buntings, had increased (Figure 3).

Similarly, a general increase in the surface of reed habitats and fewer reed-rush formations were observed when the analysis was performed for high-interest regions (Figure 5). The variation in the reed-rush formations' surface area was analyzed during the period before the extinction of reed buntings (between 2005 and 2006) with a chi-square test of equality of proportions. This decrease was significant in Regions $1\left(\chi^{2}=7.12, p<0.01\right)$ and $3\left(\chi^{2}=7.12, p<0.01\right)$. For the other regions, the differences between 2005 and 2006 were not significant (Region 2: $\chi^{2}=0.23, p=0.63$; Region $4: \chi^{2}=3.14$, $p=0.07$; Region 5: $\chi^{2}=3.33, p=0.06$ ). At the same time, the surface occupied by pure reed increased in all regions, and this increase was significant for Regions 1 and 4 (Region 1: $\chi^{2}=$ 20.21, $p<0.01$; Region 2: $\chi^{2}=1.77, p=0.18$; Region $3: \chi^{2}=0.17$,

Table 2. Accuracy test results for the classification maps.

\begin{tabular}{lrrrc}
\hline \hline \multicolumn{1}{c}{ Map Year } & 2005 & 2006 & 2008 & 2009 \\
\hline Overall accuracy (\%) & 96.38 & 95.86 & 89.31 & 85.4 \\
Kappa coefficient & 0.95 & 0.95 & 0.86 & 0.81 \\
\hline
\end{tabular}


Table 3. Changes in area coverage for the main wetland vegetation classes.

\begin{tabular}{|c|c|c|c|c|c|c|c|c|}
\hline \multirow[b]{2}{*}{ Landcover Class } & \multicolumn{4}{|c|}{ Area (ha) } & \multicolumn{4}{|c|}{ Relative Change in Area (\%) } \\
\hline & 2005 & 2006 & 2008 & 2009 & $2005-06$ & $2006-08$ & 2008-09 & $2005-09$ \\
\hline Reed & 294.50 & 358.07 & 334.83 & 270.95 & 21.59 & -6.49 & -19.08 & -7.99 \\
\hline Reed-rush & 106.12 & 37.93 & 60.66 & 27.83 & -64.25 & 59.92 & -54.12 & -73.77 \\
\hline Reed-cattail & 117.94 & 41.22 & 46.32 & 114.75 & -54.05 & 12.37 & 147.73 & -2.70 \\
\hline Grassland & 50.50 & 60.12 & 48.33 & 13.20 & 19.04 & -19.61 & -72.68 & -73.86 \\
\hline Rushes & 20.64 & 50.78 & 12.38 & 34.88 & 146.02 & -75.62 & 181.74 & 68.99 \\
\hline Reed-bulrushes & 7.25 & 2.32 & 14.97 & 42.20 & -68.00 & 545.26 & 181.89 & 482.06 \\
\hline
\end{tabular}

$p=0.67$, Region $4: \chi^{2}=8.38, p<0.01$; Region $5: \chi^{2}=0.08, p=$ $0.78)$.

When analyzing vegetation variation inside the random circular areas, the proportion of reed-rush was higher at the beginning of the study (Figure 6), with significant differences found between study years (analysis of variance: $F_{3,200}=3.133$, $p=0.026$ ). A post hoc Tukey's test analysis almost showed significant differences between 2005 and $2009(p=0.02)$ and between 2005 and 2006 ( $p=0.09$ ).

\section{DISCUSSION}

This study demonstrates how basic processing and classification techniques combined with medium-high-resolution satellite images can be applied to obtain a satisfactory classification of several key vegetation types of small coastal wetlands and, complementarily, to assess the habitat suitability of endangered species. Here, it is discussed how the selection of suitable spatial resolution for images, appropriate image corrections, and validation methods provides an opportunity to obtain useful and reliable contemporary and past ecological information to study habitats of animal species (Fuller et al., 2005; Gillespie et al., 2008; Keith et al., 2009).

The spatial resolution of the SPOT-5 images $(10 \mathrm{~m})$ was high enough to conduct the habitat analysis for the studied species. The small breeding territories of reed buntings (following Brickle and Peach, 2004; Vera et al., 2014) led to ruling out other medium-resolution satellite images (such as Landsat images), because the number of pixels inside each territory would have been too small to perform a proper analysis of the habitat within all these territories. The results of the global classification accuracy of each map confirmed that the band number and the

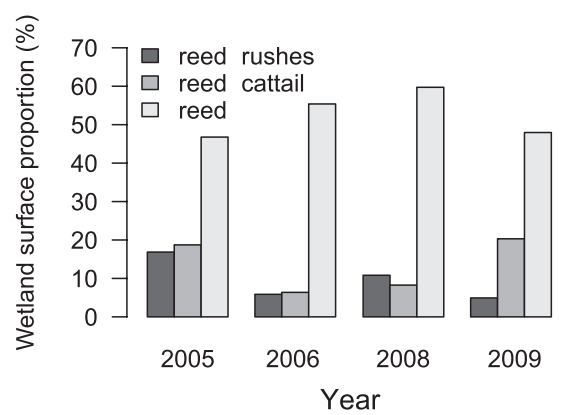

Figure 3. Proportions of the key vegetation formations on a wetland scale, showing an abrupt general decrease of mixed reed formations (habitats positively selected by the study species), together with an increase of pure reed (negatively selected) between 2005 and 2006 . spectral resolution of the SPOT-5 images were appropriate for making a supervised classification in the study area.

The accuracy analysis of the 2008 classification based on the field map gave $74 \%$ accuracy, a lower value than that obtained with the global accuracy analysis (89\%, accuracy based on the selected ROIs). This smaller value could be because of the inconsistency of the spatial and temporary scales in the accuracy measurement methodology performed with the field map. First, field-based validations should be planned beforehand (Strahler et al., 2006). However, this was not possible, because satellite images from previous years were used and the only field information available was from 2008. Predicting the dates on which images will be captured can be of considerable help in appropriate validation analyses. Second, classification validations should be performed on either the same or a comparable spatial scale as the satellite images (Strahler et al., 2006). In this study, the field map was created on a smaller scale in certain zones (narrow paths and small crops) and on bigger scales in other zones (some central vegetation patches of the wetland). ROIs were created in areas where mapping was more intense (smaller scale) to ensure that each ROI was a uniform vegetation unit. Field map-based validation was performed for the whole map to obtain classification errors associated with scale differences between the field map and the satellite image resolution.

It is common to find such a scale inconsistency when validating classification maps with field data. Hence, it is important to calculate global accuracy and the kappa coefficient using the

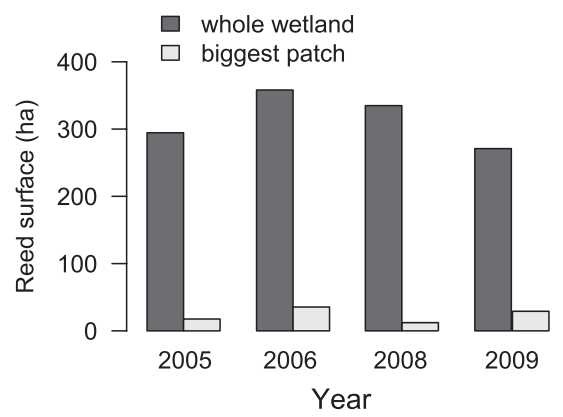

Figure 4. Total pure reed surface on a wetland scale (in hectares) and the surface of the biggest reed patch (in hectares) for each study year. A general increase of pure reed surface, together with the increase of the patch sizes of these formations, could indicate a general decrease of the habitat suitability for the study species. The figure shows an increase of pure reed surface between 2005 and 2006, although the rest of the values fluctuate for the rest of the years. 

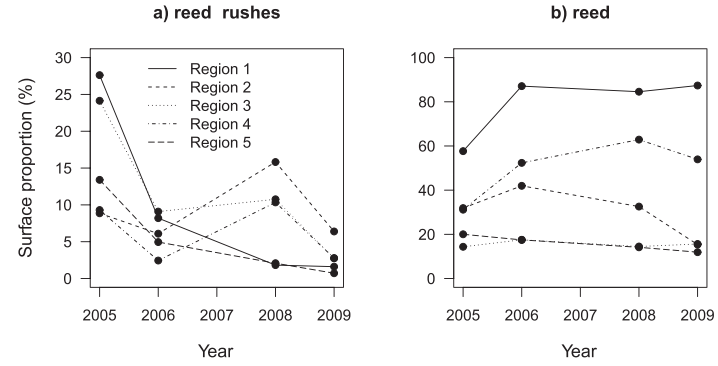

Figure 5. Surface proportions of reed-rushes (a) and pure reeds (b) for all analyzed ROIs for each study year. A general decrease of the reed-rushes proportions was observed between 2005 and 2006 within the ROIs, areas with high probability of occurrence for the study species. Similar patterns can be observed between 2008 and 2009. An increase of the proportion of reed was observed between 2005 and 2006 for the regions where the study species was recorded during the study period (Regions 1 and 2).

ROIs at the same time (Richards, 2006). In this case, relatively high-accuracy values were obtained for all classification maps compared with previous works conducted in wetlands (Baker et al., 2006; Davranche, Lefebvre, and Poulin, 2010; Ozesmi and Bauer, 2002). Pure reed formations showed high-accuracy values, but lower-accuracy values and poorer separability indices were obtained for grasslands and mixed vegetation formations (see Supplementary Appendices A and B), as previous studies conducted in wetlands using SPOT-5 images have reported. For example, in their wetland vegetation classification, Davranche, Lefebvre, and Poulin (2009) obtained 98\% accuracy values for pure reeds, while for other vegetation types, they obtained smaller values (around 86\%). Conchedda, Durieux, and Mayaux (2007) also obtained accuracy values that ranged from $73 \%$ to $98 \%$, depending on the vegetation type. Future developments for wetland classifications, such as the use of multiseasonal or hyperspectral data, should focus on improving the accuracy of mixed formations and partially flooded vegetation, because these formations are often key for the study of the distribution of many animal species living in these ecosystems.

The observed vegetation dynamics were used to understand the population dynamics of reed buntings in relation to the availability of suitable habitats. Regions 1 and 2, where all observations of territorial males were recorded, suffered a homogenization process with a decrease in the reed-rush surface, the most important vegetation formation for the species, and suffered an important increase in pure reed, a habitat that reed buntings avoid (Vera et al., 2011). Despite observing a general increase in the reed-rush coverage in 2008, the percentage of this key formation decreased again the following year in most regions, as well as on a wetland scale. In accordance with the lack of recovery of suitable habitats in Regions 1 and 2, as well as in the rest of the ROIs, no colonizing territorial males were detected in the study area from 2008. In addition, on the territory scale, the randomly selected areas showed a significant decrease in preferred habitats and a significant increase in habitats avoided by the reed buntings, suggesting a generalized reduction of suitable habitat for the species.

Differences in the vegetation changes between regions could indicate differential land management for different parts of the

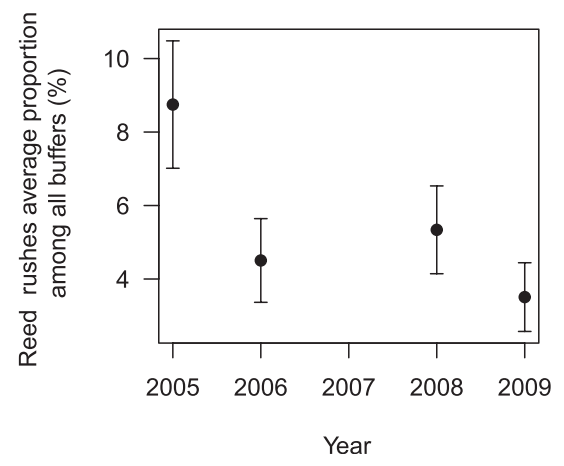

Figure 6. Average of the proportion of reed-rush formations inside the analyzed random circular areas, showing a significant decrease of suitable habitats for the species at a territorial scale. Error bars indicate the standard error of the mean.

wetland. Abandonment of crops and livestock activities could have affected the vegetation dynamics of some regions (Urios and Menargues, 2005) while having limited influence on other regions. Further analysis should investigate which particular areas could have been altered by these management changes to observe correlations with the vegetation dynamics. Because the most drastic changes in terms of management took place before the present study, the analysis of satellite images before 2005 could help to clarify the effect of these transformations. These results suggest that longstanding monitoring in these types of wetlands, naturally driven by severe meteorological events such as flooding and droughts, as well as by human-related uses (i.e. reed cutting and grazing), should be oriented to detect interannual vegetation changes. Long-term variability studies are often unable to detect severe, rapid changes in the habitat availability of small animal populations. Monitoring programs with rapid and systematized methods would help to reveal habitat changes, easing the decision-making process to avoid wetland degradation.

The observed interannual vegetation changes suggest a relationship between the decline in reed buntings and the reduction in suitable habitats for their territory establishment and with landscape homogenization. Although the sudden habitat change occurred between 2005 and 2006, in the form of a rush-reed dominancy change, and the suitable vegetation types for territory establishment continued to reduce, reed bunting extinction occurred in the wetland under study between 2007 and 2008. Like other animal species, a reduction in the number of bird territories occurred with a certain time lag, which varied among species and alteration types (Brooks, Pimm, and Oyugi, 1999; Findlay and Bourdages, 2001). Campbell (1988) observed a 2-year delay between habitat alteration and reduction in the number of territories of reed buntings in a riparian habitat.

Beyond the scope of vegetation dynamics, particular factors exist that can lead to the decline and extinction of reed bunting populations. Among them are found interspecific competition (Báldi, 2004, 2006), availability of trophic resources (Martin, 1992, 1995; Pärt, 2001), and nest predation risk (Musilová et al., 2014; Schiegg, Eger, and Pasinelli, 2007; Trnka, Peterková, 
and Grujbárová, 2011). These factors cannot be directly analyzed by remote sensing techniques but are closely linked to the structure and coverage of vegetation (e.g., Pasinelli and Schiegg, 2006). Recently, Musilová et al. (2014) found that the eutrophication and deterioration of tussock sedges led to an increased probability of predation in nests built on top of this vegetation type. It is also fundamental to consider, alongside previously discussed processes, stochastic environmental changes and population fluctuations, because they can lead to the extinction of small and isolated populations or species with a metapopulation structure, such as reed buntings.

\section{CONGLUSIONS}

This study showed how a posteriori monitoring can help in understanding the vegetation dynamics of coastal wetlands and the rapid changes that can take place in the habitats of threatened species that live in them. On the basis of this study, ecologists and land managers should be encouraged to select appropriate images and classification workflows carefully and to plan field validation campaigns in detail by focusing on scale factors and relatively identifiable land types from satellite imagery (Wang et al., 2009). Satellite images, when combined with field-based maps to produce high-accuracy vegetation mapping, are key to monitoring biodiversity habitat availability, especially among endangered species. The medium-highresolution images increasingly available from high-revisitingfrequency satellites, such as those from the recently launched Sentinel satellites (Berger et al., 2012), have the potential to be a gamechanger for researchers monitoring rapid habitat changes of threatened ecosystems.

\section{ACKNOWLEDGMENTS}

The authors thank the authorities of the Marjal Pego-Oliva Natural Park for providing the facilities to work in protected areas and for the relevant permits. This study has been funded by projects CGL2005-02041/BOS and CGL201021933-C02-02 from the Spanish Ministry of Education and Science. P. Vera was granted research support by Spanish Ornithological Society/BirdLife in 2008. Nacho Encabo and Marcial Marín helped with the fieldwork in 2006 and 2007.

\section{LITERATURE CITED}

Allan, J.D. and Flecker, A.S., 1993. Biodiversity conservation in running waters. BioScience, 43(1), 32-43.

Atienza, J.C., 2006. El Escribano palustre en España. I Censo Nacional (2005). Madrid: Spanish Ornithological Society/BirdLife, $72 \mathrm{p}$ (in Spanish).

Baker, C.; Lawrence, R.; Montagne, C., and Patten, D., 2006. Mapping wetlands and riparian areas using Landsat ETM+ imagery and decision-tree-based models. Wetlands, 26(2), 465-474.

Báldi, A., 2004. Area requirements of passerine birds in the reed archipelago of Lake Velence, Hungary. Acta Zoologica Academiae Scientiarum Hungaricae, 50(1), 1-8.

Báldi, A., 2006. Factors influencing occurrence of passerines in the reed archipelago of Lake Velence (Hungary). Acta Ornitholica, 46(1), 1-12.

Berger, M.; Moreno, J.; Johannessen, J.A.; Levelt, P.F., and Hanssen, R.F., 2012. ESA's sentinel missions in support of Earth system science. Remote Sensing of Environment, 120, 84-90.

Beyer, H.L., 2002. Hawth's Analysis Tools for ArcGIS. http://www. spatialecology.com/htools.
Brickle, N.W. and Peach, W.J., 2004. The breeding ecology of reed buntings Emberiza schoeniclus in farmland and wetland habitats in lowland England. Ibis, 146(S2), S69-S77.

Brooks, T.M.; Pimm, S.L., and Oyugi, J.O., 1999. Time lag between deforestation and bird extinction in tropical forest fragments. Conservation Biology, 13(5), 1140-1150.

Byers, C.; Olson, U., and Curson, J., 1995. Buntings and Sparrows: A Guide to the Buntings and North American Sparrows. Boston: Houghton Mifflin, 334p.

Campbell, L.H., 1988. The impact of river engineering on water birds on an English lowland river. Bird Study, 35(2), 91-96.

Chuvieco, E., 2002. Teledetección Ambiental. Madrid: Ariel, 594p.

Conchedda, G.; Durieux, L., and Mayaux, P., 2007. Object-based monitoring of land cover changes in mangrove ecosystems of Senegal. Proceedings of the International Workshop on the Analysis of Multi-temporal Remote Sensing Images (Leuven, Belgium), pp. $1-6$.

Congalton, R., 1991. A review of assessing the accuracy of classifications of remotely sensed data. Remote Sensing of Environment, 37(1), 35-46.

Darwall, W.; Smith, K.; Allen, D.; Seddon, M.; McGregor-Reid, G.; Clausnitzer, V., and Kalkman, V.J., 2009. Freshwater biodiversity-A hidden resource under threat. In: Vie, J.C.; Hilton-Taylor, C., and Stuart, S.N. (eds.), Wildlife in a Changing World: An Analysis of the 2008 IUCN Red List of Threatened Species. Gland, Switzerland: International Union for Conservation of Nature, pp. 43-54.

Davranche, A.; Lefebvre, G., and Poulin, B., 2009. Radiometric normalization of SPOT 5 scenes: $6 \mathrm{~S}$ atmospheric model versus pseudo-invariant features. Photogrammetric Engineering and Remote Sensing, 75(6), 723-728.

Davranche, A.; Lefebvre, G., and Poulin, B., 2010. Wetland monitoring using classification trees and SPOT-5 seasonal time series. Remote Sensing of Environment, 114(3), 552-562.

De Roeck, E.R.; Verhoest, N.E.C.; Hiya, M.H.; Lievens, H.; Batelaan, O.; Thomas, A., and Brendonck, L., 2008. Remote sensing and wetland ecology: A South African case study. Sensors, 8(5), 3542-3556.

Dudgeon, D.; Arthington, A.H.; Gessner, M.O.; Kawabata, Z.; Knowler, D.J.; Lévêque, C.; Naiman, R.J.; Prieur-Richard, A.H.; Soto, D.; Stiassny, M.L., and Sullivan, C.A., 2006. Freshwater biodiversity: Importance, threats, status and conservation challenges. Biological Reviews of the Cambridge Philosophical Society, 81(2), 163-182.

Environmental Systems Research Institute, 2009. ArcMap 9.2. Redlands, California: Environmental Systems Research Institute.

Findlay, C.S. and Bourdages, J., 2001. Response time of wetland biodiversity to road construction on adjacent lands. Conservation Biology, 14(1), 86-94

Fuller, R.M.; Devereux, B.J.; Gillings, S.; Amable, G.S., and Hill, R.A., 2005. Indices of bird-habitat preference from field surveys of birds and remote sensing of land cover: A study of south-eastern England with wider implications for conservation and biodiversity assessment. Global Ecology and Biogeography, 14(3), 223-239.

Gillespie, T.W.; Foody, G.M.; Rocchini, D.; Giorgi, A.P., and Saatchi, S., 2008. Measuring and modeling biodiversity from space. Progress in Physical Geography, 32(2), 203-221.

Gottschalk, T.K.; Huettmann, F., and Ehlers, M., 2005. Thirty years of analyzing and modeling avian habitat relationships using satellite imagery data: A review. International Journal of Remote Sensing, 26(2), 2631-2656.

Haig, S.M. and Mehlman, D.W., 1998. Avian movements and wetland connectivity in landscape conservation. Conservation Biology, 12(4), 749-758.

Keith, D.A.; Orscheg, C.; Simpson, C.C.; Clarke, P.J.; Hughes, L.; Kennelly, S.J.; Major, R.E.; Soderquist, T.R.; Wilson, A.L., and Bedward, M., 2009. A new approach and case study for estimating extent and rates of habitat loss for ecological communities. Biological Conservation, 142(7), 1469-1479.

Klemas, V., 2011. Remote sensing of wetlands: Case studies comparing practical techniques. Journal of Coastal Research, $27(3), 418-427$.

Klemas, V., 2013. Using remote sensing to select and monitor wetland restoration sites: An overview. Journal of Coastal Research, 29(4), 958-970. 
Leyequien, E.; Verrelst, J.; Slot, M.; Schaepman-Strub, G.; Heitkönig, I.M.A., and Skidmore, A., 2007. Capturing the fugitive: Applying remote sensing to terrestrial animal distribution and diversity. International Journal of Applied Earth Observation and Geoinformation, 9(1), 1-20.

Madroño, A.; Gonzalez, C., and Atienza, J.C., 2004. Libro rojo de las aves de España. Madrid: Dirección General de la BiodiversidadSpanish Ornithological Society/BirdLife, 452p (in Spanish).

Martin, L.; Howarth, P.J., and Holder, G.H., 1998. Multispectral classification of land use at the rural-urban fringe using Spot data. Canadian Journal of Remote Sensing, 14(2), 72-79.

Martin, T.E., 1992. Interaction of nest predation and food limitation in reproductive strategies. Current Ornithology, 9, 163-197.

Martin, T.E., 1995. Avian life history evolution in relation to nest sites, nest predation, and food. Ecological Monographs, 65(1), 101127.

Martínez-Vilalta, J.; Bertolero, A.; Bigas, D.; Paquet, J.Y., and Martínez-Vilalta, A., 2002. Habitat selection of passerine birds nesting in the Ebro Delta reedbeds (NE Spain): Management implications. Wetlands, 22(2), 318-325.

Melack, J.M. and Hess, L.L., 2004. Remote sensing of wetlands on a global scale. Limnology, 42, 1-5.

Mialon, A.; Royer, A., and Fily, M., 2005. Wetland seasonal dynamics and interannual variability over northern high latitudes, derived from microwave satellite data. Journal of Geophysical Research, 110(D17102), 1-9.

Musilová, Z.; Musil, P.; Zouhar, J., and Poláková, S., 2014. Nest survival in the reed bunting Emberiza schoeniclus in fragmented wetland habitats: The effect of nest-site selection. Ornis Fennica, 91(3), 138-148.

Ozesmi, S.L. and Bauer, M.E., 2002. Satellite remote sensing of wetlands. Wetlands Ecology and Management, 10(5), 381-402.

Pärt, T., 2001. Experimental evidence of environmental effects on agespecific reproductive success: The importance of resource quality. Proceedings of the Royal Society of London B, 268(1482), 2267-2271.

Pasinelli, G. and Schiegg, K., 2006. Fragmentation within and between wetland reserves: The importance of spatial scales for nest predation in reed buntings. Ecography, 29(5), 721-732.

Poulin, B.; Davranche, A., and Lefebvre, G., 2010. Ecological assessment of Phragmites australis wetlands using multi-season SPOT-5 scenes. Remote Sensing of Environment, 114(7), 1602-1609.

Poulin, B. and Lefebvre, G., 2002. Effect of winter cutting on the passerine breeding assemblage in French Mediterranean reedbeds. Biodiversity and Conservation, 11(9), 1567-1581.

Poulin, B.; Lefebvre, G., and Mauchamp, A., 2002. Habitat requirements of passerines and reedbed management in southern France. Biological Conservation, 107(3), 315-325.

Revenga, C.; Campbell, I.; Abell, R.; De Villiers, P., and Bryer, M., 2005. Prospects for monitoring freshwater ecosystems toward the 2010 targets. Philosophical Transactions Royal Society of London B, 360(1454), 397-413.
Richards, J.A., 2006. Remote Sensing Digital Image Analysis. Berlin: Springer-Verlag, 516p.

Rocchini, D.; Hortal, J.; Lengyel, S.; Lobo, J.M.; Jiménez-Valverde, A.; Ricotta, C.; Giovanni, B., and Chiarucci, A., 2011. Accounting for uncertainty when mapping species distribution: The need for maps of ignorance. Progress in Physical Geography, 35(2), 211-226.

Schiegg, K.; Eger, M., and Pasinelli, G., 2007. Nest predation in reed buntings Emberiza schoeniclus: An experimental study. Ibis, 149(2), 365-372.

Shirley, S.M.; Yang, Z.; Hutchinson, R.A.; Alexander, J.D.; McGarigal, K., and Betts, G., 2013. Species distribution modelling for the people: Unclassified Landsat TM imagery predicts bird occurrence at fine resolutions. Diversity and Distributions, 19(7), 855-866.

Strahler, A.H.; Boschetti, L.; Foody, G.M.; Friedl, M.A.; Hansen, M.C.; Herold, M.; Mayaux, P.; Morisette, J.T.; Stehman, S.V., and Woodcock, C.E., 2006. Global Land Cover Validation: Recommendations for Evaluation and Accuracy Assessment of Global Land Cover Maps. Luxembourg: European Commission, EUR 22156 EN-DG, 48p.

Strayer, D.L. and Dudgeon, D., 2010. Freshwater biodiversity conservation: Recent progress and future challenges. Journal of the North American Benthological Society, 29(1), 344-358.

Tanneberger, F.; Tegetmeyer, C.; Dylawerski, M.; Flade, M., and Joosten, H., 2009. Commercially cut reed as a new and sustainable habitat for the globally threatened aquatic warbler. Biodiversity and Conservation, 18(6), 1475-1489.

Trnka, A.; Peterková, V., and Grujbárová, Z., 2011. Does reed bunting (Emberiza schoeniclus) predict the risk of nest predation when choosing a breeding territory? An experimental study. Ornis Fennica, 88(3), 179-184.

Turner, W.; Spector, S.; Gardiner, N.; Fladeland, M.; Sterling, E., and Steininger, M., 2003. Remote sensing for biodiversity science and conservation. Trends in Ecology and Evolution, 18(6), 306-314.

Urios, V. and Menargues, M.A., 2005. Gestión del carrizo a través de la ganadería en el Parque Natural del Marjal de Pego Oliva, Alicante-Valencia (España). I Jornadas sobre biodiversidad y los carrizales de los humedales del sur de Alicante, Crevillente (Alicante), 23-25 (in Spanish).

Vera, P.; Belda, E.F.; Kvist, L.; Encabo, S.I.; Marín, M., and Monrós, J.S., 2014. Habitat preferences for territory selection by the endangered Eastern Iberian reed bunting Emberiza Schoeniclus witherbyi. Ardeola, 61(1), 97-110.

Vera, P.; Belda, E.J.; Kvist, L.; Encabo, S.I., and Monrós, J.S., 2011. Habitat preference of the endangered Eastern Iberian reed bunting. Bird Study, 58(3), 238-247.

Vera, P.; Marín, M.; Belda, E.J., and Monrós, J.S., 2009. Estructura y composición del nido de Escribano Palustre Iberoriental Emberiza schoeniclus witherbyi. Revista Catalana de Ornitologia, 25, 43-48 (in Spanish).

Wang, K.; Franklin, S.E.; Guo, X.; He, Y., and McDermid, G.J., 2009. Problems in remote sensing of landscapes and habitats. Progress in Physical Geography, 33(6), 1-22.

\section{$\square$ RESUMEN $\square$}

Los humedales costeros son ecosistemas altamente dinámicos debido a los efectos de la meteorología, las interacciones entre especies y las actividades humanas. Estos ecosistemas se encuentran entre los más amenazados del planeta, y en muchas ocasiones abocan a las especies más especialistas que viven en ellas a estados de conservación y tendencias poblacionales desfavorables. Un seguimiento frecuente de los cambios en la cobertura de los diferentes tipos de vegetación es de gran importancia para entender la dinámica de las poblaciones de estas especies. Sin embargo, la realización de una cartografía detallada y frecuente conlleva un gran esfuerzo económico y de trabajo. En el presente estudio, se combinaron imágenes de satélite con mapas de campo para crear mapas de vegetación de años anteriores utilizando imágenes SPOT-5 del humedal costero de Pego-Oliva (España), obteniendo porcentajes de acierto por encima del $85 \%$. Junto con modelos de selección de hábitat, se utilizaron estos mapas para analizar los cambios del hábitat de una especie de ave amenazada, el escribano palustre iberoriental (Emberiza schoeniclus witherby), cuyas poblaciones han sufrido un gran declive en España en las últimas décadas. Se observó una reducción significativa en parcelas de carrizoenea (hábitat seleccionado positivamente) y un incremento homogéneo de carrizo puro (hábitat seleccionado negativamente) en áreas donde la especie ha desaparecido como nidificante. Nuestro estudio demuestra el potencial de las técnicas de teledetección y GIS para un seguimiento a posteriori de la variación de los hábitats disponibles para especies amenazadas, con el objetivo de establecer medidas de gestión y conservación. 